
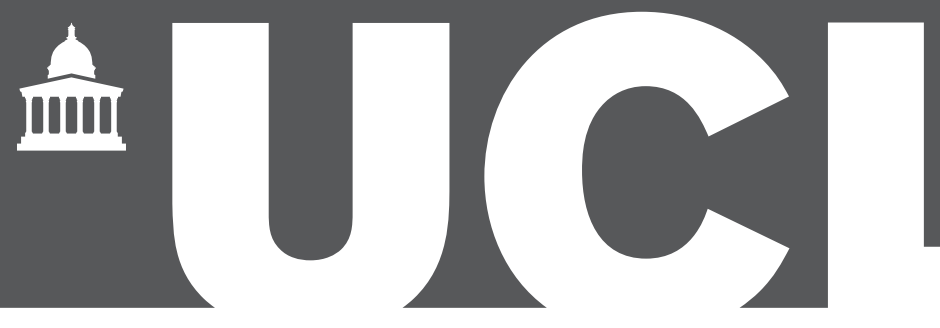

\title{
THE CONSTITUTIONAL STANDARDS OF THE HOUSE OF LORDS SELECT COMMITTEE ON THE CONSTITUTION
}

Jack Simson Caird, Robert Hazell and Dawn Oliver

The Constitution Unit 


\section{The Constitutional Standards of the House of Lords Select Committee on the Constitution}

Jack Simson Caird, Robert Hazell and Dawn Oliver

ANCI 
ISBN: 978-1-903903-66-7

Published by The Constitution Unit

School of Public Policy

University College London

29-30 Tavistock Square

London WC1H 9QU

Tel: 02076794977 Fax: 02076794978

Email: constitution@ucl.ac.uk

Web: www.ucl.ac.uk/constitution-unit

(C) The Constitution Unit, UCL 2013

This report is sold subject to the condition that is shall not, by way of trade or otherwise, be lent, hired out or otherwise circulated without the publisher's prior consent in any form of binding or cover other than that in which it is published and without a similar condition including this condition being imposed on the subsequent purchaser.

First Published January 2014 


\section{Contents}

Genesis of this project $\quad 5$

$\begin{array}{ll}\text { Introduction } & 6\end{array}$

A Code of Constitutional Standards based upon the reports of the House of Lords Select Committee on the Constitution 10

1) The rule of law 10

$\begin{array}{ll}1.1 \text { Retrospective legislation } & 10\end{array}$

1.2 Legal certainty 11

2) Delegated powers, delegated legislation and Henry VIII clauses 11

2.1 Defining the power 11

2.2 Safeguards in delegation of legislative powers 11

$\begin{array}{ll}2.3 \text { Appropriate uses of delegated powers } & 12\end{array}$

2.4 The parliamentary justification of delegated powers,
delegated legislation and Henry VIII powers

3) The separation of powers 12

$\begin{array}{ll}3.1 \text { The judiciary } & 12\end{array}$

3.2 The Government 13

$\begin{array}{ll}3.3 \text { Parliament } & 16\end{array}$

4) Individual rights 16

4.1 General principles 16

4.2 Access to justice 17

$\begin{array}{ll}4.3 \text { Natural justice } & 17\end{array}$

5) Parliamentary procedure 18

$\begin{array}{ll}5.1 \text { Pre-legislative scrutiny } & 18\end{array}$

$\begin{array}{ll}5.2 \text { Explanatory Notes } & 19\end{array}$

5.3 Bills with constitutional implications $\quad 20$

5.4 Fast-track legislation $\quad 21$

5.5 Responding to a committee's report 22

5.6 Amendments 23

5.7 Post-legislative scrutiny 23 
Appendix: List of the Reports of the House of Lords Select Committee on the Constitution

1. 2001-2002 24

2. $2002-2003$

3. $2003-2004$

4. $2004-2005$

5. $2005-2006$

6. 2006-2007 32

7. $2007-2008$

8. $2008-2009$

9. $2009-2010$

10. $2010-2012$

11. $2012-2013$ 


\section{Genesis of this project}

Dawn Oliver advocated the development of legislative standards in her article 'Improving the Scrutiny of Bills: the Case for Standards and Checklists' in Public Law in 2006. Robert Hazell provided supporting arguments in two other articles in Public Law, 'Who is the Guardian of Legal Values in the Legislative Process: Parliament or the Executive?' (2004), and 'Time for a new Convention: Parliamentary Scrutiny of Constitutional Bills' (2006).

In 2013 these ideas were revived at a panel session on 'Parliament and fundamental values' at the Study of Parliament Group's annual conference. The panel was organised by Murray Hunt, Legal Adviser to the parliamentary Joint Committee on Human Rights. After the panel Robert Hazell suggested to Dawn Oliver that it was time to demonstrate that a set of legislative standards could be developed, and this project was born. Jack Simson Caird has done the hard work of going through all the reports of the House of Lords Constitution Committee, extracting their standards and assembling them into coherent form.

The study was kindly funded by Nat Le Roux, Director of the Constitution Society. We are very grateful for his financial support, without which this project would not have been possible. 


\section{Introduction}

This report codifies the constitutional standards used by the House of Lords Select Committee on the Constitution (hereafter the Constitution Committee) in their reports published between 2001 and the end of the parliamentary session of 2012-2013. The 149 reports are all listed in the Appendix.

In 2006 Dawn Oliver, professor of constitutional law at University College London, made the case for the use of standards and checklists within the legislative process in Westminster. ${ }^{1}$ Oliver argued that the adoption and use of a set of standards, along the lines of the one outlined in this report, by both Parliament and Government 'would improve the quality of Bills presented to Parliament, enhance the capacity of Parliament to perform its scrutiny and consent-giving functions effectively, and thus improve the quality of the legislation Parliament passes'. ${ }^{2}$

This codification exercise has three principal goals. The first is to draw attention to the normative foundations of the work of the Constitution Committee. The Constitution Committee was established in 2001 following a recommendation of the Royal Commission on the reform of the House of Lords. ${ }^{3}$ The Committee's formal terms of reference were set by the House of Lords Liaison Committee and have not changed since then: 'to examine the constitutional implications of all public Bills coming before the House; and to keep under review the operation of the constitution'. ${ }^{4}$ The Constitution Committee has used this remit to establish itself as a key constitutional actor. It has done this by producing important investigative reports that contribute to current debates on the constitution, and by publishing reports on the constitutional implications of Government bills, some of which have proved highly influential. ${ }^{5}$ The Committee's influence and status derives from its ability to articulate, interpret and develop the norms of the British constitution that are relevant to the scrutiny process.

The code contained within this report aims to highlight how the Committee has developed constitutional standards that relate to the legislative process. The standards identified within this report concern both the content of legislation and the practice of the legislative process. In this sense, the code is intended to make the Committee's constitutional interpretation more transparent. 
In its first report, the Committee explained that it defined the constitution as being made up of five main tenets:

- Sovereignty of the Crown in Parliament

- The Rule of Law, encompassing the rights of the individual

- Union State

- Representative Government

- Membership of the Commonwealth, the European Union, and other international organisations. ${ }^{6}$

The Committee also explained that scrutiny would focus on those aspects of bills that raised 'significant constitutional issues'. ${ }^{7}$ They defined a constitutionally significant issue to be 'one that is a principal part of the constitutional framework and one that raises an important question of principle'. ${ }^{8}$ This provided a useful starting point. What is of particular interest is how, in practice, the Committee interprets the constitution. The code of standards below reveals how the five tenets and definition of 'significant constitutional issues' have been applied in the context of the legislative process and to the content of legislation. While it is important to recognise that the majority of the standards contained in the code were extracted from the Committee's reports on particular bills, the fact that many of the standards can be identified in multiple reports shows that the Committee has adopted a number of clear and consistent positions on the meaning of certain constitutional norms in the legislative context. By expounding the meaning of the constitution in this way the Committee has performed a vital service to constitutionalism in the United Kingdom: it has demonstrated the relevance of the normative content of the constitution to the lawmaking process. It is hoped that this code highlights this contribution.

The second goal of this exercise is to provide a potential resource for those involved in the legislative process. The code could be used within government. It could be referred to in the Cabinet Office 'Guide to Making Legislation', to inform those preparing bills of the standards likely to be raised by the Constitution Committee in the Lords. ${ }^{9}$ It could also be used by individual parliamentarians engaged in legislative scrutiny. Publication of a code that makes these standards more accessible to parliamentarians might prompt more of them to apply them in the course of the analysis and scrutiny of a bill. The code could also be used by the Constitution Committee itself as a basis to develop their standards, which they could update annually. It is hard to think of a good reason for not making more use of soft law standards in the legislative process. They are not binding, and so they fit well within the flexible nature and spirit of the constitution; and yet their interpretation and application, even in the

$6 \quad$ House of Lords Constitution Committee, Reviewing the Constitution: Terms of Reference and Method of Working (HL 2001$02,11)$ para 21.

7 House of Lords Constitution Committee, Reviewing the Constitution: Terms of Reference and Method of Working (HL 2001$02,11)$ para 23

$8 \quad$ House of Lords Constitution Committee, Reviewing the Constitution: Terms of Reference and Method of Working (HL 200102, 11) para 23.

$9 \quad$ The work of the Constitution Committee (32.12), the Joint Committee on Human Rights (11.31) and the work of the House of Lords Delegated Powers and Regulatory Reform Committee (15) are covered by the Guide: Cabinet Office, The Guide to Making Legislation (London: 2013) https:/www.gov.uk/government/uploads/system/uploads/attachment_data/file/210917/ Guide_to_Making_Legislation_July_2013.pdf. 
context of disagreement over their meaning or importance, can serve to raise the issue of justification for the proposed provision within the legislative process.

The third goal of this exercise is to contribute to the debate on the development of a code of general legislative standards that was begun by the House of Commons Select Committee on Political and Constitutional Reform (hereafter the PCRC). In their report titled 'Ensuring standards in the quality of legislation', the PCRC recommends that 'that there should be a Code of Legislative Standards for good quality legislation agreed between Parliament and the Government' and that 'a Joint Legislative Standards Committee with an oversight role should be created'. ${ }^{10}$ The report contains a Draft Code of Legislative Standards, which is said to draw together 'existing practice and guidelines within Parliament and work already completed by groups such as the Hansard Society and Better Government Initiative, as well as academic writing and examples from other countries'. ${ }^{11}$ The report adds that their draft code should be used 'as the basis for discussion and agreement between Parliament and the Government as to legislative standards'. ${ }^{12}$ The code included in this report demonstrates that the scrutiny work of the Constitution Committee is also relevant to that debate, and that in reality a set of legislative standards, based on the constitution, has already been developed within Parliament.

The Government's response to the PCRC's report, published in July 2013, indicates that a general code of legislative standards is not going to materialise:

'The Government does not believe that a Code of Legislative Standards is necessary or would be effective in ensuring quality legislation.' ${ }^{13}$

If we are not going to have a general code of legislative standards, it is up to Parliament and its committees to build on the PCRC's proposal, and to develop other ways in which codes of standards can play a role in the legislative process. While Government support may be needed for a general code to be workable, there is nothing to prevent individual committees following the example of the PCRC and developing their own set of standards.

It is important to remember that the code is not supposed to represent a definitive list of constitutional or legislative norms, nor it is intended to be binding on any constitutional actor. The idea of the code is to provide a list of the constitutional standards that have been developed incrementally by the parliamentary committee that has responsibility for constitutional issues. It can provide a platform for debate and a resource for Report of Session 2013-14 (HC 85) p 3. would improve the quality of the legislative process: Ruth Fox and Matt Korris, Making Better Law: Reform of the legislative process from policy to Act (Hansard Society, 2010); Better Government Initiative, Good Government: Reforming Parliament and the Executive (2010). 
participants in the legislative process. The standards within this code cannot resolve the key political questions that arise during the legislative process, but they can serve to provide a normative framework for some of those questions. The point of a soft-law code of standards is that, while a breach or departure from a standard is not necessarily undesirable, it should be acknowledged and justified by those responsible.

\section{Methodology}

Extracting the constitutional standards from the Constitution Committee's reports is not a precise science. There is an unavoidable degree of subjectivity to the exercise. The basic methodology was to record every reference to a norm that related to either the content of legislation or the legislative process itself. The first sift involved reading through reports and recording every norm within each report. The result of this sift is included in the Appendix.

To produce the code, we categorised the norms catalogued in the initial sift under headings and then amalgamated some of the standards so as to avoid repetition. When two or more standards overlapped to a significant degree they were collapsed into one standard and the relevant footnote contains all the references to the separate standards.

The main problem is that it is not always crystal clear when the Constitution Committee is referring to a standard. In general terms we have erred on the side of caution, and have tried to be as faithful as possible to the text of the report. As already mentioned, in the Committee's scrutiny reports the Committee is not setting out general standards, but putting forward its view on a particular bill. We do not infer from these reports, and from their inclusion in our code that the Committee intended a point to be of general application. There is little doubt that if the Committee were to produce its own code based on its reports, it would take its own distinct approach.

The important thing to bear in mind is that the Committee is rarely categorical. It is rare for it to say legislation should not do $\mathrm{x}$ or legislation should do y. However, the Committee nonetheless draws attention to possible departures from constitutional principles, and in the process it often specifies fairly clear standards. It is these that we have attempted to extract.

The footnotes to the Code list the sources as Report 1, etc. The full references can be found in the Appendix, which numbers the Committee's reports sequentially from 1 to 149 . 


\section{A Code of Constitutional Standards based on the reports of the House of Lords Select Committee on the Constitution}

\section{1) The rule of law}

\subsection{Retrospective legislation}

1.1.1 Enacting legislation with retrospective effect should be avoided. ${ }^{14}$

1.1.2 Provisions that have retrospective effect should be drafted as narrowly as possible. ${ }^{15}$

1.1.3 Individuals should not be punished or penalised for contravening what was at the time a valid legal requirement. ${ }^{16}$

1.1.4 Laws should not retrospectively interfere with obligations when the liberty or criminal liability of the citizen is at stake. ${ }^{17}$

1.1.5 Laws should not deprive someone of the benefit of a judgment already obtained. ${ }^{18}$

1.1.6 Laws should not prevent a court from deciding pending litigation according to its merits on the basis of the law in force at the time when the proceedings were commenced. ${ }^{19}$

1.1.7 Retrospective legislation should only be used when there is a compelling reason to do so. ${ }^{20}$

1.1.8 A legislative power to make a provision which has retrospective effect should be justified on the basis of 'necessity' and not of 'desirability'. ${ }^{21}$ 


\subsection{Legal certainty}

1.2.1 The rule of law requires laws to be reasonably certain and accessible. ${ }^{22}$

1.2.2 General warrants should be avoided. ${ }^{23}$

1.2.3 Laws that include a variable monetary penalty should include an upper limit. ${ }^{24}$

\section{2) Delegated powers, delegated legislation and Henry VIII clauses}

\subsection{Defining the power}

2.1.1 Delegations of legislative power should be framed as narrowly as possible. ${ }^{25}$

2.1.2 The policy aims of a Ministerial power should be included in the bill itself. ${ }^{26}$

2.1.3 The scope of a Henry VIII power should be limited to the minimum necessary to meet the pressing need for such an exceptional measure. ${ }^{27}$

2.1.4 The use of Henry VIII powers should only be permitted if specific purposes are provided for in the Bill. ${ }^{28}$

2.1.5 Ministerial powers should be defined objectively. ${ }^{29}$

2.1.6 Ministerial powers to make secondary legislation should be restricted by effective legal boundaries. ${ }^{30}$

\subsection{Safeguards in delegation of legislative powers}

2.2.1 Laws that contain delegated powers should strike a balance between the desire for effectiveness and the safeguards needed to ensure constitutional propriety. ${ }^{31}$

Reports 64, 113 and 123.

Report 44.

Report 64.

Reports 12, 30 and 49.

Reports 41 and 145.

Reports 51, 77, 93 and 130.

Reports 116 and 137.

Report 51.

Report 51.

Report 64. 
2.2.2 If constitutional safeguards can be added to a delegated ministerial legislative power without undermining the policy goals of a Bill then they should be included. ${ }^{32}$

2.2.3 Henry VIII powers should be accompanied by adequate procedural and legal safeguards. ${ }^{33}$

2.2.4 Henry VIII powers that relate to a constitutionally sensitive subject-matter should use a super-affirmative parliamentary procedure. ${ }^{34}$

2.2.5 Ministers should not be able to suspend legal powers by giving directions; instead orders, which are subject to parliamentary oversight, should be used. ${ }^{35}$

2.2.6 Provision should be made for Parliament to be informed promptly of all ministerial exercises of legislative power. ${ }^{36}$

\subsection{Appropriate uses of delegated powers}

2.3.1 Henry VIII clauses should be limited so that they cannot be used to alter constitutional arrangements. ${ }^{37}$

2.3.2 Laws should not permit the sub-delegation of legislative powers. ${ }^{38}$

2.3.3 Delegating order-making powers to Ministers to change the statute book should be avoided when there are other more constitutionally appropriate alternatives available. ${ }^{39}$

2.3.4 Delegated legislation should not be used to create regulations that will have a major impact on the individual's right to respect for private life. ${ }^{40}$

2.3.5 Delegated legislation should not be used to create new criminal offences. ${ }^{41}$

2.3.6 Bills should identify the provisions in other enactments that require amendment, rather than using Henry VIII powers to leave the power to make amendments to the subsequent discretion of the relevant department. ${ }^{42}$

Report 51.

Reports 51, 77, 116, 137.

Report 138.

Report 64.

Report 25.

Reports 25, 39 and 51.

Report 51.

Report 86.

Report 90.

Report 93.

Report 93. 
2.3.7 The most important aspects of a policy should be included on the face of a bill and not left to be decided through delegated legislation. ${ }^{43}$

2.3.8 Rules that are central to a bill of constitutional significance should be to the greatest extent possible on the face of the bill, so allowing full legislative amendment and debate. ${ }^{44}$

2.3.9 Rights of appeal should be defined in primary legislation and not in secondary legislation. ${ }^{45}$

2.3.10 Delegations of legislative authority should fit within the overall scheme of the bill. ${ }^{46}$

\subsection{The parliamentary justification of delegated powers, delegated legislation and Henry VIII powers}

2.4.1 Ministers should provide Parliament with their justifications for proposing the delegation of legislative powers. ${ }^{47}$

2.4.2 Ministerial assurances as to the purpose of order-making powers are not a substitute for legal safeguards on the face of a Bill. ${ }^{48}$

2.4.3 Widely-drawn delegations of legislative authority cannot be exclusively justified by the need for speed. ${ }^{49}$

2.4.4 The justification for a Henry VIII clause should refer to the specific purpose that it is designed to serve..$^{50}$

2.4.5 Where an "incidental and consequential" Henry VIII power is likely to be used in relation to constitutional legislation, the Government should provide a clear and detailed account to Parliament of how and why it intends to exercise that power. ${ }^{51}$

\section{3) The separation of powers}

\subsection{The judiciary}

3.1.1 The independence of the judiciary should not be undermined. ${ }^{52}$

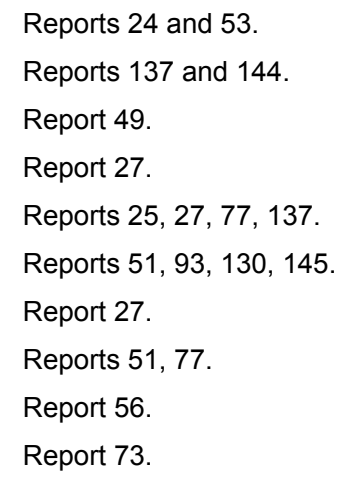


3.1.2 Judges' security of tenure should be preserved. ${ }^{53}$

3.1.3 The politicisation of the judicial appointments process should be avoided ${ }^{54}$

3.1.4 Ouster clauses should be avoided. ${ }^{55}$

3.1.5 The exercise of powers to combat terrorism should be subject to adequate judicial control. ${ }^{56}$

3.1.6 The roles of Parliament and the judiciary should not be conflated. ${ }^{57}$

3.1.7 If a government minister is to be made responsible for judiciary-related matters, then that minister should be the Lord Chancellor. ${ }^{58}$

3.1.8 Coercive powers that restrict a constitutional right should be exercised by the judiciary rather than the executive. ${ }^{59}$

3.1.9 The nature of the judicial oversight of a ministerial power should be clear on the face of the bill. ${ }^{60}$

3.1.10 Laws should avoid creating the possibility of conflict between Parliament and the courts. ${ }^{61}$

3.1.11 A Minister's legal accountability to the courts should not be fragmented. ${ }^{62}$

3.1.12 Interference with the courts' ability to decide on the appropriate balance between the competing public interests of national security and the proper administration of justice should be avoided. ${ }^{63}$

3.1.13 Laws should not grant powers to the Secretary of State that unduly risk the fair administration of justice. ${ }^{64}$

3.1.14 Case management issues should be decided by the courts and not by Government ministers. ${ }^{65}$

$\begin{array}{ll}53 & \text { Report } 21 . \\ 54 & \text { Report } 137 . \\ 55 & \text { Report } 60 . \\ 56 & \text { Report 73. } \\ 57 & \text { Report 73. } \\ 58 & \text { Reports 73 and 80. } \\ 59 & \text { Report 83. } \\ 60 & \text { Reports } 84 \text { and } 129 . \\ 61 & \text { Report } 91 . \\ 62 & \text { Reports } 128 \text { and } 132 . \\ 63 & \text { Report } 138 . \\ 64 & \text { Report } 138 . \\ 65 & \text { Report } 138 .\end{array}$




\subsection{The Government}

3.2.1 Parliamentary debate and legislative authorisation should precede, not follow, the establishment of a public body. ${ }^{66}$

3.2.2 Public authorities established by Act of Parliament ought to derive their principal powers from express legal provisions. ${ }^{67}$

3.2.3 Government should not be granted legal authority in excess of the powers properly needed to implement a proposed policy. ${ }^{68}$

3.2.4 An independent system of regulation should be underpinned by laws that make provision to ensure its political neutrality. ${ }^{69}$

3.2.5 The decision-making powers of a public authority should be subject to the possibility of appeal to a different body. ${ }^{70}$

3.2.6 Laws should not jeopardise the operational independence of the police. ${ }^{71}$

3.2.7 The executive should not be allowed to have the dual role in civil proceedings of being a party to the litigation and at the same time being the sole "gatekeeper", controlling access to the possibility that the litigation be conducted in a certain manner. $^{72}$

3.2.8 Legislative sanction powers should not be administered by a private sector business. $^{73}$

3.2.9 Ministerial assurances as to the use of administrative sanction powers are not a substitute for legal safeguards on the face of a Bill. ${ }^{74}$

3.2.10 Ministerial assurances are no substitute for a statutory sunset clause. ${ }^{75}$

3.2.11 Sunset clauses should be included when provisions are introduced for reasons of expediency in one Session ahead of a bill on the same subject that is forthcoming. ${ }^{76}$

$\begin{array}{ll}66 & \text { Report } 49 . \\ 67 & \text { Report } 57 . \\ 68 & \text { Report } 81 . \\ 69 & \text { Report } 92 . \\ 70 & \text { Report } 92 . \\ 71 & \text { Report } 124 . \\ 72 & \text { Report 138. } \\ 73 & \text { Report 83. } \\ 74 & \text { Report 83. } \\ 75 & \text { Report } 72 . \\ 76 & \text { Reports } 72 \text { and } 73 .\end{array}$


3.2.12 Laws should not risk or impair the principle of individual ministerial responsibility to Parliament. ${ }^{77}$

3.2.13 Laws should respect the principle that the revenue affairs of individuals should be kept at arm's length from ministers. ${ }^{78}$

\subsection{Parliament}

3.3.1 Laws should not impede effective parliamentary scrutiny. ${ }^{79}$

3.3.2 Laws should not add unnecessary complexity to the law-making process. ${ }^{80}$

3.3.3 The Government should not unduly restrict parliamentary deliberation. ${ }^{81}$

3.3.4 Omnibus Bills hinder legislative scrutiny and should be avoided. ${ }^{82}$

3.3.5 The principle of parliamentary privilege should be respected. ${ }^{83}$

3.3.6 It is not appropriate for Parliament to act unilaterally to reinterpret an international treaty to which the UK has become a party. ${ }^{84}$

3.3.7 Laws should not interfere with the principle that no person or body is recognised by the law of England as having a right to override or set aside the legislation of Parliament save where this is specifically authorized by Act of Parliament. ${ }^{85}$

3.3.8 Legislation should respect the fundamental constitutional principle that no Parliament may bind its successors. ${ }^{86}$

\section{4) Individual rights}

\subsection{General principles}

4.1.1 The restriction of individual rights should be proportionate. ${ }^{87}$

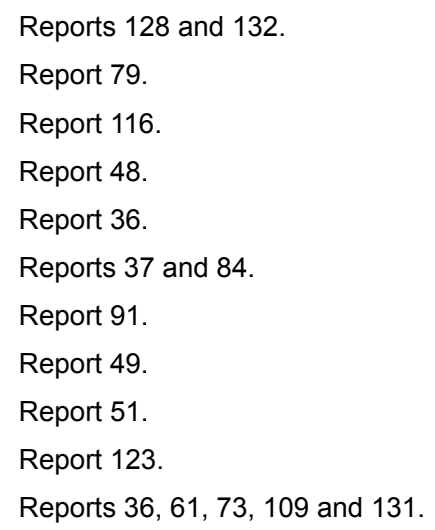


4.1.2 Provisions that restrict the liberty of the individual should be drafted as narrowly as possible. ${ }^{88}$

4.1.3 Provisions that restrict the liberty of the individual should be accompanied by sufficient limits and protections. ${ }^{89}$

4.1.4 Severe restrictions on the liberty of the subject should only be the result of a criminal conviction..$^{90}$

4.1.5 Voluntary assurances should not be regarded as a satisfactory substitute for legally enforceable rights. ${ }^{91}$

\subsection{Access to justice}

4.2.1 Laws should respect the constitutional right of access to justice. ${ }^{92}$

4.2.2 A statutory power granted to a public body to deprive an individual of a significant right should be subject to a reference by the public body to a court. ${ }^{93}$

4.2.3 Laws should respect the constitutional principle that individual liberty is to be protected by the courts. ${ }^{94}$

\subsection{Due process and procedural fairness}

4.3.1 Laws that create a power to make administrative decisions that affect individuals should meet the minimum standards of procedural fairness. ${ }^{95}$

4.3.2 The common law principle of natural justice: audi alteram partem (hear both sides before making a decision) should be respected. ${ }^{96}$

4.3.3 The right to a fair trial should be respected. ${ }^{97}$

4.3.4 Laws that confer upon the executive coercive sanction powers should include safeguards for ensuring that fair procedures are followed and that there is an effective appeal to the courts to ensure judicial oversight. ${ }^{98}$ 
4.3.5 Laws that create a public decision-making process should ensure that affected citizens have recourse to an effective appeal system. ${ }^{99}$

4.3.6 Laws which impose restriction on the freedom of individuals backed by sanctions should include basic due process safeguards. ${ }^{100}$

4.3.7 Laws should respect the right of an individual detained in a police station to free legal advice. ${ }^{101}$

\section{5) Parliamentary procedure}

\subsection{Pre-legislative scrutiny}

5.1.1 Government Bills should be published in draft. ${ }^{102}$

5.1.2 Draft Bills should represent a properly rounded set of proposals. ${ }^{103}$

5.1.3 When a Government Bill is not published in draft, the explanatory notes should set out the reasons. ${ }^{104}$

5.1.4 The Government should ensure that the full text of draft Bills is available to prelegislative scrutiny committees in good time before they are asked to report. ${ }^{105}$

5.1.5 Joint Committees should be set up at least two sitting weeks before a draft Bill is published and not be required to report until at least one month after the end of the consultation period. In the absence of a formal consultation exercise on the part of the Government, the minimum should be 4 months from publication of draft Bills. ${ }^{106}$

5.1.6 A committee considering a draft Bill should be supplied with the findings of a consultation exercise, and the Government's response to those findings should be made available to it. ${ }^{107}$

5.1.7 Draft Bills should be published in good time, and should allow at least twelve weeks for scrutiny at a minimum. ${ }^{108}$

Report 75.

Report 90.

Report 131.

Reports 4 and 31

Report 97.

Report 31.

Report 31.

Report 31.

Report 31.

Reports 67, 71 and 104. 
5.1.8 Publication of draft Bills should be spread across the parliamentary year. ${ }^{109}$

5.1.9 The Government should issue a formal response to a committee report on a draft Bill. ${ }^{110}$

5.1.10 The Government should provide a written statement to the House when measures contained in a draft Bill are not pursued or where the provisions in a draft Bill are substantially amended or combined with other proposals in subsequent legislation. ${ }^{111}$

5.1.11 When a Government response to a committee report on draft legislation is delayed beyond two months, the Government should write to the Committee concerned to explain the delay. ${ }^{112}$

5.1.12 If a draft Bill announced as part of the Government's legislative programme is not subsequently brought forward, the Government should, by the end of the session, make a written statement to the House explaining the delay. ${ }^{113}$

\subsection{Explanatory Notes}

5.2.1 The Explanatory Notes to each Bill should include, in the introductory section, a clear and developed explanation of the purpose of the Bill, incorporating or accompanied by the criteria by which the Bill, once enacted, can be judged to have met its purpose. ${ }^{114}$

5.2.2 Where a Bill amends an earlier Act, the effects of the Bill on the Act should be shown in an informal print of the amended Act and should be included in the Explanatory Notes to the Bill. ${ }^{115}$

5.2.3 The Explanatory Notes to all Bills introduced to give effect to EU obligations should carry a section detailing the scrutiny history of the measure. ${ }^{116}$

5.2.4 Explanatory notes to a Bill should draw attention to significant departures from the Draft Bill. ${ }^{117}$ 


\subsection{Bills with constitutional implications}

5.3.1 When the Government introduces a Bill it should provide a written ministerial statement which indicates whether, in each minister's view, the Bill provides for significant constitutional change and, if so:

- what is the impact of the proposals upon the existing constitutional arrangements;

- whether and, if so, how the Government engaged with the public in the initial development of the policy proposals and what was the outcome of that public engagement;

- in what way were the detailed policies contained in the Bill subjected to rigorous scrutiny in the Cabinet committee system;

- whether a green paper was published, what consultation took place on the proposals, including with the devolved institutions, and the extent to which the Government agree or disagree with the responses given;

- whether a white paper was published and whether pre-legislative scrutiny was undertaken and the extent to which the Government agree or disagree with the outcome of that process;

- what is the justification for any referendum held, or to be held, on the proposals;

- and when and how the legislation, if passed, will be subject to post-legislative scrutiny. ${ }^{118}$

5.3.2 The Government should provide Parliament with its justification for the constitutional implications of legislation when it introduces a Bill. ${ }^{119}$

5.3.3 The committee stage of Bills of first class constitutional importance should be taken on the floor of the House of Commons. ${ }^{120}$

5.3.4 The process of enacting Bills of constitutional importance should meet the requirements of caution and proportionality. ${ }^{121}$

5.3.5 Bills that contain issues of constitutional significance should be published by the Government in draft and subject to pre-legislative scrutiny. ${ }^{122}$ 
5.3.6 Significant constitutional legislation should be subject to full scrutiny by both Houses of Parliament, and should not be fast-tracked, unless there are justifiable reasons for fast-tracking them. ${ }^{123}$

5.3.7 The Government should not introduce substantially new clauses to a constitutionally significant Bill if there is not enough time to scrutinise them adequately in both Houses of Parliament. ${ }^{124}$

5.3.8 Bills of major constitutional significance should not find their way onto the statute book via the 'wash-up'. 125

5.3.9 Referendums should only be used to decide fundamental constitutional issues. ${ }^{126}$

\subsection{Fast-track legislation}

5.4.1 The fast-tracking of normal parliamentary procedure should only occur when strictly necessary. ${ }^{127}$

5.4.2 Fast-track legislation should not be used by government to address legal issues that have been known about for a long time. ${ }^{128}$

5.4.3 Fast-track legislation should be made available to Parliament's legislative scrutiny committees at the earliest possible opportunity, even while the legislation remains in draft form. ${ }^{129}$

5.4.4 Fast-track legislation should not be used to overturn a court judgment retrospectively in order to deprive an individual of a right. ${ }^{130}$

5.4.5 The Minister responsible for a fast-tracked Bill should be required to make an oral statement to the House of Lords outlining the case for fast-tracking. ${ }^{131}$

5.4.6 The Minister responsible for a fast-tracked Bill should be required to issue a written memorandum which addresses the following points:

(a) Why is fast-tracking necessary?

$\begin{array}{ll}123 & \text { Reports 80, 91, 107, } 140 \text { and } 146 . \\ 124 & \text { Report } 107 . \\ 125 & \text { Report } 107 . \\ 126 & \text { Report 123. } \\ 127 & \text { Report } 146 . \\ 128 & \text { Report } 143 . \\ 129 & \text { Report } 143 . \\ 130 & \text { Report } 147 . \\ 131 & \text { Reports } 89 \text { and } 101 .\end{array}$


(b) What is the justification for fast-tracking each element of the Bill?

(c) What efforts have been made to ensure the amount of time made available for parliamentary scrutiny has been maximised?

(d) To what extent have interested parties and outside groups been given an opportunity to influence the policy proposal?

(e) Does the Bill include a sunset clause (as well as any appropriate renewal procedure)? If not, why do the Government judge that their inclusion is not appropriate?

(f) Are mechanisms for effective post-legislative scrutiny and review in place? If not, why do the Government judge that their inclusion is not appropriate?

(g) Has an assessment been made as to whether existing legislation is sufficient to deal with any or all of the issues in question?

(h) Have relevant parliamentary committees been given the opportunity to scrutinise the legislation? ${ }^{132}$

5.4.7 When a Bill is fast-tracked there should be a presumption in favour of the inclusion of a sunset clause. ${ }^{133}$

5.4.8 When a Bill is fast-tracked it should be subject to post-legislative review within a maximum of two years post-enactment. ${ }^{134}$

5.4.9 Fast-track legislation should not be used to retrospectively overturn a court judgment where there is no compelling operational requirement to amend the law retrospectively. ${ }^{135}$

\subsection{Responding to a committee's report}

5.5.1 If the Constitution Committee reports on a Bill before second reading, the Government should respond before the commencement of the committee stage. ${ }^{136}$ 


\subsection{Amendments}

5.6.1 The late tabling of amendments should be minimised. ${ }^{137}$

\subsection{Post-legislative scrutiny}

5.7.1 The Government should explain their position on post-legislative scrutiny of the Bill prior to its enactment. ${ }^{138}$

5.7.2 Constitutional legislation should be subject to comprehensive post-legislative scrutiny. ${ }^{139}$ 


\section{Appendix: List of the Reports of the House of Lords Select Committee on the Constitution 2001-02 to 2012-13}

1. 2001-2002

1. First Report: Reviewing the Constitution: Terms of Reference and Method of Working (First Report) (HL Paper 11) None.

2. Anti-Terrorism, Crime and Security Bill (Second Report) (HL Paper 41) Provision should be made for prompt access to a court or tribunal for the resolution of disputes between individuals and the state and disputes between individuals (Appendix).

3. Sex Discrimination (Election Candidates) Bill (Third Report) (HL Paper 41) None.

4. Changing the Constitution: The Process of Constitutional Change (Fourth Report) (HL Paper 69)

Government bills should be published in draft (para 40).

5. Justice (Northern Ireland) Bill (Fifth Report) (HL Paper 42) None.

6. Nationality, Immigration and Asylum Bill (Sixth Report) (HL Paper 95) None.

7. Nationality, Immigration and Asylum Bill Further Report (Seventh Report) (HL Paper 129)

Laws should not have retrospective effect (paras 6- 8).

Laws should not retrospectively interfere with obligations when the liberty or criminal liability of the citizen is at stake (para 7).

Legislation should respect the principle of legal certainty (para 9).

Laws should not deprive someone of the benefit of a judgment already obtained (para 10). 
Laws should not prevent a court deciding pending litigation according to its merits on the basis of the law in force at the time when the proceedings were commenced (para 11).

\section{2002-2003}

8. Crime (International Co-operation) Bill [HL] (First Report) (HL Paper 27) None.

9. Devolution: Inter-Institutional Relations in the United Kingdom (Second Report) (HL Paper 28)

None.

10. Courts Bill [HL] (Third Report) (HL Paper 38)

None

11. Regional Assemblies (Preparations) Bill (Fourth Report) (HL Paper 56) None.

12. European Parliament (Representation) Bill (Fifth Report) (HL Paper 65)

Powers to make subordinate legislation should be drawn as narrowly as practicable (para 4).

13. Extradition Bill (Sixth Report) (HL Paper 82)

None.

14. Criminal Justice Bill (Seventh Report) (HL Paper 129)

None.

15. Health and Social Care (Community Health and Standards) Bill (Eighth Report) (HL Paper 156)

None.

16. The Draft Constitutional Treaty for the European Union (Ninth Report) (HL Paper 168)

None.

17. Meeting with the Lord Chancellor (Tenth Report) (HL Paper 180) None. 


\section{2003-2004}

18. European Parliamentary and Local Elections (Pilots) Bill (First Report) (HL Paper 16)

None.

19 Annual Report (2002-2003) (Second Report) (HL Paper 19) None.

20. Planning and Compulsory Purchase Bill (Third Report) (HL Paper 27) None.

21. Justice (Northern Ireland) Bill (Fourth Report) (HL Paper 40) Judges' security of tenure should be preserved (Appendix 1).

22. Companies (Audit, Investigation and Community Enterprise) Bill (Fifth Report) (HL Paper 53)

None.

23. The Regulatory State: Ensuring its Accountability (Sixth Report) (HL Paper 68) None.

24. Gangmasters (Licensing) Bill (Seventh Report) (HL Paper 108)

The main objectives of a legislative scheme should be apparent from the face of a Bill and should not be left to secondary legislation (paras 4-8).

25. Civil Contingencies Bill (Eight Report) (HL paper 114)

Henry VIII clauses must be clearly justified (para 7).

Provision should be made for Parliament to be informed promptly of all ministerial exercises of legislative power (para 12)

Henry VIII clauses should be drafted so that they cannot be used to amend constitutional enactments (paras 13-15).

26. Children Bill (Ninth Report) (HL Paper 123) None.

27. Age-Related Payments Bill (Tenth Report) (HL Paper 124)

Delegations of legislative authority should be justified (para 10).

Delegations of legislative authority should be narrowly defined (para 10).

Delegations of legislative authority should fit within the overall scheme of a Bill (para 9). 
28. Constitutional Reform Bill (Eleventh Report) (HL paper 142)

None.

29. The Regulatory State: Ensuring its Accountability (Twelfth Report) (HL Paper 150) None.

30. Age-Related Payments Act (Thirteenth Report) (HL Paper 172)

Widely-drawn delegations of legislative authority cannot be exclusively justified by the need for speed (para 6).

31. Parliament and the Legislative Process (Fourteenth Report) (HL Paper 178)

Government bills should be published in draft (para 34).

When a Government bill is not published in draft, the explanatory notes should set out the reasons to explain the reasons behind the decision (para 34).

The Government should ensure that the full text of draft Bills is available to prelegislative scrutiny committees in good time before they are asked to report (para 63).

Joint Committees should be set up at least two sitting weeks before a draft bill is published and not be required to report until at least one month after the end of the consultation period. In the absence of a formal consultation exercise on the part of the Government, the minimum should be 4 months from publication of draft bills (para 69).

A committee considering a draft bill should be supplied with the findings of a consultation exercise, and the Government's response to those findings should be made available to it (para 71).

The Explanatory Notes to each bill should include, in the introductory section, a clear and developed explanation of the purpose of the bill, incorporating or accompanied by the criteria by which the bill, once enacted, can be judged to have met its purpose (para 87).

Where a bill amends an earlier Act, the effects of the bill on the Act should be shown in an informal print of the amended Act and should be included in the Explanatory Notes to the bill (para 98).

The Explanatory Notes to all bills introduced to give effect to EU obligations should carry a section detailing the scrutiny history of the measure (para 103).

32. Devolution: Its Effect on the Practice of Legislation at Westminster (Fifteenth Report) (HL Paper 192)

None. 
33. Meeting with the Lord Chancellor (Sixteenth Report) (HL Paper 193) None.

34. Annual Report 2003-04 (Seventeenth Report) (HL Paper 194) None.

\section{2004-2005}

35. Inquiries Bill (First Report) (HL Paper 21)

Bills of constitutional significance should be subject to pre-legislative scrutiny (Appendix 1).

36. Prevention of Terrorism Bill (Second Report) (HL Paper 66)

The Government should not unduly restrict parliamentary deliberation (para 13).

Provisions of constitutional significance that make far-reaching inroads into the liberties of the individual must be strongly justified (para 15).

37. Serious Organised Crime and Police Bill (Third Report) (HL Paper 65) Legislative proposals which command political consensus should not be used as a vehicle for legislating on more contentious matters that should be the subject of separate legislation (para 2).

38. First Progress Report 2004-05 (Fourth Report) (HL Paper 78) When legislation makes extensive amendments to previous legislation the Government should take steps, such as publishing a Keeling style Bill, to make the legislation comprehensible (para 4).

39. Identity Cards Bill (Fifth Report) (HL Paper 82)

Significant changes to the relationship between the State and the individual should not be brought about by secondary legislation (para 12).

40. Parliament and the Legislative Process: The Government's Response (Sixth Report) (HL Paper 114)

None.

\section{2005-2006}

41. First Progress Report 2005-06 (First Report) (HL Paper 30)

The policy aims of a Ministerial power should be included in the Bill itself (para 6). 
42. Second Progress Report 2005-06 (Second Report) (HL Paper 47)

None.

43. Identity Cards Bill (Third Report) (HL Paper 44)

Significant changes to the relationship between the State and the individual should not be brought about by secondary legislation (para 9).

44. Terrorism Bill (Fourth Report) (HL Paper 82)

General warrants should be avoided (para 4).

Legislative provisions that are only needed for a limited time should include sunset clauses the provision for regular post-legislative scrutiny (para 5).

The restriction of individual rights should be proportionate (para 6).

45. Constitutional Reform Act 2005 (Fifth Report) (HL Paper 83)

None.

46. $\quad$ Meeting with the Lord Chancellor (Sixth Report) (HL Paper 84) None.

47. Constitutional aspects of the challenge to the Hunting Act 2004 (Seventh Report) (HL Paper 141)

None.

48. Government of Wales Bill (Eighth Report) (HL Paper 142)

Laws should not add unnecessary complexity to the law-making process (para 31).

49. Third Progress Report (Ninth Report) (HL Paper 151)

When legislation makes extensive amendments to previous legislation the Government should take steps, such as publishing a Keeling version of the Bill, to make the legislation easier to comprehend (para 4).

Rights of appeal should be set out in primary and not secondary legislation (para 9-10).

There needs to be a strong justification for legislation that proposes to restrict an individual's rights of appeal (Appendix 3 - para 4).

It is not appropriate for Parliament to act unilaterally to reinterpret an international treaty to which the UK has become a party (Appendix 3 - para 8).

Parliamentary debate and legislative authorisation should precede, not follow, the establishment of a public body (Appendix 4).

Delegations of legislative power should be framed as narrowly as possible (Appendix 5 - para 3). 
50. Government Response to a report on the Government of Wales Bill (Tenth Report) (HL Paper 168)

None.

51. Legislative and Regulatory Reform Bill (Eleventh Report) (HL Paper 194)

Bills of constitutional significance should be published in draft (para 1).

Ministerial powers to make secondary legislation should be restricted by effective legal boundaries (para 8).

The committee stage of Bills of first class constitutional importance should be taken on the floor of the House of Commons (para 19).

The government should provide Parliament with its justification for the constitutional implications of legislation when it introduces a Bill (para 21).

Ministerial assurances as to the purpose of order-making powers are not a substitute for legal safeguards on the face of a Bill (para 23).

Laws should not interfere with the principle that no person or body is recognised by the law of England as having a right to override or set aside the legislation of Parliament (para 32).

Henry VIII powers should be accompanied by adequate procedural and legal safeguards (para 35).

The justification for a Henry VIII clause should refer to the specific purpose that it is designed to serve (para 35).

The purpose of a Henry VIII clause should be defined in the Bill as narrowly as possible (para 36).

If constitutional safeguards can be added without undermining the policy goals of a Bill then they should included (para 45).

Henry VIII clauses should be limited so that they cannot be used to alter constitutional arrangements (para 52).

Ministerial powers should be defined objectively (para 60).

Laws should not permit the sub-delegation of legislative powers (para 61).

Order making powers should be restricted so that they do not allow the amendment of primary legislation that is less than two years old (para 62).

52. Police and Justice Bill (Twelfth Report) (HL Paper 195)

None. 
53. Armed Forces Bill (Thirteenth Report) (HL Paper 200)

The most important aspects of a policy should be included in the face of a Bill and not left to be decided through delegated legislation (para 5).

54. $\quad$ Meeting with the Lord Chief Justice (Fourteenth Report) (HL Paper 213) None.

55. Waging war: Parliament's role and responsibility (Fifteenth Report) (HL Paper 236) None.

56. Final Progress Report 2005-06 (Sixteenth Report) (HL Paper 255)

Laws should not have retrospective effect (para 4).

Where an "incidental and consequential" Henry VIII power is likely to be used in relation to constitutional legislation, there is a need for a clear and detailed account of how and why the Government intends to exercise that power (Appendix 5).

\section{2006-2007}

57. Tribunals, Courts and Enforcement Bill (First Report) (HL Paper 13)

Public authorities established by Act of Parliament ought to derive their principal powers from express legal provisions (para 12).

Laws should not interfere with the constitutional principle of access to justice (paras 14-16).

58. Serious Crime Bill (Second Report) (HL Paper 41)

Provisions that restrict the liberty of the individual should be drafted as narrowly as possible (para 12).

Provisions that restrict the liberty of the individual should be accompanied by sufficient limits and protections (para 14).

Severe restrictions on the liberty of the subject should be the result of a criminal conviction (para 17).

59. Waging war: Parliament's role and responsibility Follow-up (Third Report) (HL Paper 51)

None.

60. Justice and Security (Northern Ireland) Bill (Fourth Report) (HL Paper 54) Ouster clauses should be avoided (para 2). 
61. Freedom of Information (Amendment) Bill (Fifth Report) (HL Paper 127) The process of enacting Bills of constitutional importance should meet the requirements of caution and proportionality (para 4).

Voluntary assurances should not be regarded as a satisfactory substitute for legally enforceable rights (para 8).

Restrictions on the right to access information should be narrowly drawn and proportionate (paras 12-14).

62. Relations between the executive, the judiciary and Parliament (Sixth Report) (HL Paper 151)

None.

63. The Governance of Britain (Seventh Report) (HL Paper 158) None.

\section{2007-2008}

64. Regulatory Enforcement and Sanctions Bill (First Report) (HL Paper 16) Laws should strike a balance between the desire for effectiveness and the safeguards needed to ensure constitutional propriety (para 2).

Laws should be reasonably certain and accessible (para 6).

Ministers should not be able to suspend legal powers by giving directions; instead orders, which are subject to parliamentary oversight, should be used (para 6).

Laws that creates a power to make administrative decisions should meet the minimum standards of procedural fairness (para 11).

The common law principle of natural justice: audi alteram partem (hear both sides before making a decision) should be respected (para 11).

Laws that creates a variable monetary penalty should include an upper limit (para 12).

65. Scrutiny of Welsh Legislative Competence Orders (Second Report) (HL Paper 17) None.

66. Child Maintenance and Other Payments Bill (Third Report) (HL Paper 27) A statutory power granted to a public body to deprive an individual of a significant right should be subject to a reference by the public body to a court (para 10). 
67. Pre-Legislative Scrutiny in the 2006-07 Session (Fourth Report) (HL Paper 43) Draft bills should be published in good time, and should allow at least twelve weeks for scrutiny at a minimum (para 21).

68. Annual Report 2006-07 (Fifth Report) (HL Paper 44) None.

69. European Union (Amendment) Bill and the Lisbon Treaty: Implications for the UK Constitution (Sixth Report) (HL Paper 84)

None.

70. Reform of the Office of Attorney General (Seventh Report) (HL Paper 93) None.

71. Pre-Legislative Scrutiny in the 2006-07 Session: Follow-up (Eighth Report) (HL Paper 129)

Draft bills should be published in good time, and should allow at least twelve weeks for scrutiny at a minimum (para 2).

72. Criminal Evidence (Witness Anonymity) Bill (Ninth Report) (HL Paper 147) The right to a fair trial should be respected (para 12).

Ministerial assurances are no substitute for a statutory sunset clause (para 20).

Sunset clauses should be included when provisions are introduced for reasons of expediency in one Session ahead of a bill on the same subject that has been announced as part of the Draft Legislative Programme for a subsequent Session (para 23).

73. Counter-Terrorism Bill: The Role of Ministers, Parliament and the Judiciary (Tenth Report) (HL Paper 167)

Laws relating to the principles of security and individual liberty should be framed proportionately (para 5).

The exercise of powers to combat terrorism should be subject to adequate judicial control (para 5).

Laws should respect the basic constitutional principle that individual liberty is to be protected by the courts (para 22).

The independence of the judiciary should not be undermined (para 38).

The roles of Parliament and the judiciary should not be conflated (para 39). 
Sunset clauses should be included when provisions are introduced for reasons of expediency in one Session ahead of a bill on the same subject that is forthcoming (para 49).

Powers to dismiss judicial officers should be conferred on the Lord Chancellor rather than upon a Secretary of State (para 57).

74. Relations between the executive, the judiciary and Parliament: Follow-up Report (Eleventh Report) (HL Paper 177)

None.

\section{2008-2009}

75. Marine and Coastal Access Bill (First Report) (HL Paper 13)

Laws that create a public decision-making process should ensure that citizens have recourse to an effective appeal system (para 13).

76. Surveillance: Citizens and the State (Second Report) ( HL Paper 18) None.

\section{Banking Bill (Third Report) (HL Paper 19)}

Henry VIII powers should only be enacted when there is a compelling justification (para 3).

The scope of a Henry VIII power should be limited to the minimum necessary to meet the pressing need for such an exceptional measure (para 3).

Henry VIII powers should be subject to parliamentary control (para 3).

Henry VIII powers cannot be justified simply by reference to a desire to make the legislative regime in question 'effective', instead they should be justified by reference to the particular context of the Bill in question (para 5).

Retrospective legislation should only be used when there is compelling reason to do so (para 7).

Provisions that have retrospective effect should be drafted as narrowly as possible (para 7).

78. Annual Report 2007-08 (Fourth Report) (HL Paper 20) None. 
79. Part 1 of the Borders, Citizenship and Immigration Bill (Fifth Report) (HL Paper 41) Laws should respect the principle that the revenue affairs of individuals should be kept at arm's length from ministers (para 2).

80. Northern Ireland Bill (Sixth Report) (HL Paper 50)

Bills that deal with issues of constitutional significance should be published in draft and subject to pre-legislative scrutiny (para 3).

Bills that deal with issues of constitutional significance should not be put on a fasttrack legislative process in the House of Commons and the House of Lords (para 9).

If a government minister is to be made responsible for judiciary-related matters, then that minister should be the Lord Chancellor (para 14).

81. Part 3 of the Borders, Citizenship and Immigration Bill (Seventh Report) (HL Paper 54)

Bills with constitutional implications should be preceded by effective consultation (para 16).

Government should not be granted legal authority in excess of the powers properly needed to implement a proposed policy (para 20).

82. Pre-Legislative Scrutiny in the 2007-08 Session (Eighth Report) (HL paper 66) Publication of draft bills should be spread across the parliamentary year (para 23).

The Government should issue a formal response to a committee report on a draft bill (para 31-32).

83. Welfare Reform Bill (Ninth Report) (HL Paper 79)

Laws that confers upon the executive powers coercive sanction powers should include measures to establish safeguards for ensuring that fair procedures are followed and that there is an effective appeal to the courts to ensure judicial oversight (para 9).

Coercive powers that restrict a constitutional right should be exercised by the judiciary rather than the executive (para 10).

Ministerial assurances as to the use of administrative sanction powers are not a substitute for legal safeguards on the face of a Bill (para 11).

Legislative sanction powers should not be administered by a private sector business (para 12).

84. Coroners and Justice Bill (Tenth Report) (HL Paper 96)

Omnibus Bills hinder legislative scrutiny and should be avoided (para 2). 
The nature of the judicial oversight of a ministerial power should be clear on the face of the bill (para 9).

85. Banking Act 2009: Supplementary report on retrospective legislation (Eleventh Report) (HL Paper 97)

A legislative power to make a provision which has retrospective effect should only invoked on the basis of 'necessity' and not of 'desirability' (para 10).

86. Law Commission Bill (Twelfth Report) (HL Paper 103)

Delegating order-making powers to Ministers to change the statute book should be avoided when there are other more constitutionally appropriate alternative available (para 2).

87. The National Assembly for Wales (Legislative Competence) (Social Welfare) Order 2009 (relating to Carers) (Thirteenth Report) (HL Paper 105)

None.

88. Analysis of the Government's response to Surveillance: Citizens and the State (Fourteenth Report) (HL Paper 114)

None.

89. Fast-track Legislation: Constitutional Implications and Safeguards (Fifteen Report) (HL Paper 116)

The late tabling of amendments should be minimised (para 106).

The Minister responsible for a fast-tracked bill should be required to make an oral statement to the House of Lords outlining the case for fast-tracking (para 184).

The Minister responsible for a fast-tracked bill should be required to issue a written memorandum which address the following points:

(a) Why is fast-tracking necessary?

(b) What is the justification for fast-tracking each element of the bill?

(c) What efforts have been made to ensure the amount of time made available for parliamentary scrutiny has been maximised?

(d) To what extent have interested parties and outside groups been given an opportunity to influence the policy proposal?

(e) Does the bill include a sunset clause (as well as any appropriate renewal procedure)? If not, why do the Government judge that their inclusion is not appropriate? 
(f) Are mechanisms for effective post-legislative scrutiny and review in place? If not, why do the Government judge that their inclusion is not appropriate?

(g) Has an assessment been made as to whether existing legislation is sufficient to deal with any or all of the issues in question?

(h) Have relevant parliamentary committees been given the opportunity to scrutinise the legislation (para 186)?

When a Bill is fast-tracked there should be a presumption in favour of the inclusion of a sunset clause (para 198).

When a Bill is fast-tracked it should be subject to post-legislative review within a maximum of two years post-enactment (para 209).

90. Policing and Crime Bill (Sixteenth Report) (HL Paper 128)

Laws which impose restriction on the freedom of individuals backed by sanctions should include basic due process safeguards (paras 6-9).

Delegated legislation should not be used to create regulations that will have a major impact on the individual's right to respect for private life (paras 11-15)

91. Parliamentary Standards Bill (Seventeenth Report) (HL Paper 130)

Bills of constitutional significance should not be fast-tracked through Parliament (para 1).

Bills of constitutional significance should be subject to pre-legislative scrutiny (para 21).

Bills of constitutional significance should be subject to public consultation (para 21).

92. Parliamentary Standards Bill: implications for Parliament and the courts (Eighteenth Report) (HL Paper 134)

An independent system of regulation should be underpinned by laws that make provision to ensure its political neutrality (paras 7-10).

Laws should avoid creating the possibility of conflict between Parliament and the courts (para 22).

The decision-making powers of a public authority should be subject to the possibility of appeal to a different body (para 34).

The principle of parliamentary privilege should be respected (para 41).

93. Co-operative and Community Benefit Societies and Credit Unions Bill (Nineteenth Report) (HL Paper 158) 
Ministerial assurances as to the purpose of order-making powers are not a substitute for legal safeguards on the face of a Bill (para 12).

Delegated legislation should not be used to create new criminal offences (para 14).

Henry VIII clauses should be drafted as narrowly as is practicable (para 20).

Bills should identify which provisions in other enactments which require amendment rather than using Henry VIII powers to leave the power to make amendments to the subsequent discretion of the relevant department (para 21).

94. The Proposed National Assembly for Wales (Legislative Competence)

(Environment) Order 2009 (Twentieth Report) (HL Paper 159)

None.

95. Government Response to a report on Pre-legislative Scrutiny in the 2007-08 session (Twenty-first Report) (HL Paper 160)

None.

96. Parliamentary Standards Bill \& Policing and Crime Bill: Government Responses to the Committee's 17th, 18th and 16th Reports of Session 2008-09 (Twenty-second Report) (HL Paper 173)

None.

\section{2009-2010}

97. Clause 12 of the Bribery Bill (First Report) (HL Paper 10)

None.

98. Government Response to Fast-Track Legislation: Constitutional Implications and Safeguards (Second Report) (HL Paper 11)

None.

99. Co-operative and Community Benefit Societies and Credit Unions Bill (Third Report) (HL Paper 17)

None.

100. The Cabinet Office and the Centre of Government (Fourth Report) (HL Paper 30) None.

101. Video Recordings Bill (Fifth Report) (HL Paper 36)

The reasons for fast-tracking legislation should be fully justified and explained to Parliament by government (paras 1-9). 
102. Clause 17 of the Digital Economy Bill (Sixth Report) (HL Paper 40)

Henry VIII powers should only be included when it can be shown that they are necessary (paras 3-4).

103. Clause 12 of the Bribery Bill: Further Report (Seventh Report) (HL Paper 49) Legislation that creates statutory defences to criminal offences specific to the executive should be subject to an authorisation procedure (para 11).

Draft Bills should represent a properly rounded set of proposals (para 12).

Explanatory notes to a Bill should draw attention to significant departures from the Draft Bill (para 13).

The Government should respond to the Committee's reports in timely fashion (para 14).

104. Pre-Legislative Scrutiny in the 2008-09 and 2009-10 Sessions (Eighth Report) (HL Paper 78)

Parliamentary committees should have a minimum of twelve weeks to report on a draft bill (para 16).

The Government should provide a written statement to the House when measures contained in a draft bill are not pursued or where the provisions in a draft bill are substantially amended or combined with other proposals in subsequent legislation (para 28).

When a Government response to a committee report on draft legislation is delayed beyond two months, the Government should write to the Committee concerned to explain the delay (para 29).

If a draft bill announced as part of the Government's legislative programme is not subsequently brought forward, the Government should, by the end of the session, make a written statement to the House explaining the delay (para 30).

105. Annual Report 2008-2009 (Ninth Report) (HL Paper 79) None.

106. Meeting with the Lord Chancellor (Tenth Report) (HL Paper 80) None.

107. Constitutional Reform and Governance Bill (Eleventh Report) (HL Paper 98)

Significant constitutional legislation should be subject to full scrutiny by both Houses of Parliament (para 40).

The government should not introduce substantially new clauses to a constitutionally 
significant Bill if there is not enough time to adequately scrutinise them in both Houses of Parliament (para 45).

Bills of major constitutional significance should not find their way onto to statute book via the 'wash-up' (para 43).

108. Referendums in the United Kingdom (Twelfth Report) (HL Paper 99)

None.

109. Crime and Security Bill (Thirteenth Report) (HL Paper 107)

Restrictions upon an individual's right to respect for private life should be proportionate (para 5).

110. Bribery Bill and Constitutional Reform and Governance Bill: Government Reponses to the Committee's $7^{\text {th }}$ and $11^{\text {th }}$ Reports of Session 2009-10 (Fourteenth Report) (HL Paper 109)

None.

111. Meeting with the Chairman of the House of Lords Appointments Commission (Fifteenth Report) (HL Paper 109)

None.

\section{2010-2012}

112. Government Response to the report on the Cabinet Office and the Centre of Government (First Report) (HL Paper 14)

None.

113. Terrorist Asset-Freezing etc. Bill (Second Report) (HL Paper 25)

Laws should not be unnecessarily complex (para 10).

Legislation that departs from the constitutional principle of legal certainty should be carefully explained (para 11).

114. Sessional Report 2009-10 (Third Report) (HL Paper 26)

None.

115. Government Response to the report on Referendums in the United Kingdom (Fourth Report) (HL Paper 34)

None.

116. The Government's Constitutional Reform Programme (Fifth Report) (HL Paper 43) None. 
117. Public Bodies Bill (Sixth Report) (HL Paper 51)

Henry VIII powers must be clearly limited, exercisable only for specific purposes, and subject to adequate parliamentary oversight (para 5).

Laws should not impede effective parliamentary scrutiny (para 6).

Legislation should only depart from constitutional principles where a full and clear explanation and justification is provided by government to Parliament (para 6).

118. Parliamentary Voting System and Constituencies Bill (Seventh Report) (HL Paper 58)

Bills that propose major constitutional reform should be subject to prior public consultation and pre-legislative scrutiny (para 12).

Referendums should only be used to decided fundamental constitutional issues (para 16).

119. Fixed-term Parliaments Bill (Eighth Report) (HL Paper 69)

The Government should explain in clear terms how constitutional reform proposals within a Bill relate to constitutional principles (para 167).

Save where there are justifiable reasons for acting more quickly, the proper way to introduce a constitutional reform proposal is to publish a green or white paper or a draft bill, and to take the comments and concerns raised in the process of consultation and pre-legislative scrutiny into account in the legislation that follows (para 179).

120. Meeting with the Lord Chief Justice and the Lord Chancellor (Ninth Report) (HL Paper 97)

None.

121. Money Bills and Commons Financial Privilege (Tenth Report) (HL Paper 97) None.

122. Meeting with Lord Jay of Ewelme, Chairman (Eleventh Report) (HL Paper 104) None.

123. The Cabinet Manual (Twelfth Report) (HL Paper 107) None.

124. European Union Bill (Thirteenth Report) (HL Paper 121)

Laws should aim to avoid complexity that will hinder transparency and accessibility in the law (para 27).

Referendums should only be used to decide fundamental constitutional issues (para 38). 
Laws should respect the fundamental constitutional principle that no Parliament may bind its successors (para 44).

125. Part 1 of the Police Reform and Social Responsibility Bill (Fourteenth Report) (HL Paper 143)

Laws should not jeopardise the operational independence of the police (para 4).

The Government should explain their position on post-legislative scrutiny of the Bill prior to its enactment (para 19).

126. The Process of Constitutional Change (Fifteenth Report) (HL Paper 177) When the Government introduces a Bill it should provide a written ministerial statement which indicates whether, in each minister's view, the bill provides for significant constitutional change and, if so:

- what is the impact of the proposals upon the existing constitutional arrangements;

- whether and, if so, how the government engaged with the public in the initial development of the policy proposals and what was the outcome of that public engagement;

- in what way were the detailed policies contained in the bill subjected to rigorous scrutiny in the Cabinet committee system;

- whether a green paper was published, what consultation took place on the proposals, including with the devolved institutions, and the extent to which the government agree or disagree with the responses given;

- whether a white paper was published and whether pre-legislative scrutiny was undertaken and the extent to which the government agree or disagree with the outcome of that process;

- what is the justification for any referendum held, or to be held, on the proposals;

- and when and how the legislation, if passed, will be subject to post-legislative scrutiny (para 71-72).

Significant constitutional legislation should be subject to pre-legislative scrutiny (para 95)

The parliamentary scrutiny of constitutional bills should not be rushed unless there are justifiable reasons for fast-tracking them (para 99).

Constitutional legislation should not be passed during the wash-up (para 99). 
Constitutional legislation should be subject to comprehensive post-legislative scrutiny (para 104).

If the Constitution Committee reports on a bill before second reading, the Government should respond before the commencement of the committee stage (para 114).

127. Police (Detention and Bail) Bill (Sixteenth Report) (HL Paper 178)

The explanatory notes to a fast-tracked Bill should explain the reasons the departing from the normal parliamentary procedure (para 5).

Parliament should be given adequate time to consider a Bill that raises questions of constitutional principle (para 7).

128. Scotland Bill (Seventeenth Report) (HL Paper 184) None.

129. The Health and Social Care Bill (Eighteenth Report) (HL Paper 197)

Laws should not risk or impair the principle of individual ministerial responsibility to Parliament (para 18).

A minister's legal accountability to the courts should not be fragmented (para 18).

130. Terrorism Prevention and Investigation Measures Bill (Nineteenth Report) (HL Paper 198)

Laws which increases the power of the executive over the liberty of the individual should be subject to adequate safeguards (para 13).

The explanatory notes are not the appropriate location for constitutionally significant directions to the courts, such matters should be clear from the face of the Bill (para 17).

131. Protection of Freedoms Bill (Twentieth Report) (HL Paper 215)

Henry VIII clauses should be drafted as narrowly as possible (para 8).

Ministerial assurances as to the purpose of order-making powers are not a substitute for legal safeguards on the face of a Bill (para 10).

132. Part 1 of the Legal Aid, Sentencing and Punishment of Offenders Bill (Twenty-First Report) (HL Report 222)

Laws should not interfere with the constitutional right of access to justice (para 5).

Restrictions upon the constitutional right of access to justice should be proportionate (para 6). 
Laws should not interfere with the right of an individual detained in a police station to free legal advice (paras 18-19).

133. Health and Social Care Bill: Follow-up (Twenty-Second Report) (HL Paper 240) Laws should not risk or impair the principle of individual ministerial responsibility to Parliament (para 1).

A minister's legal accountability to the courts should not be fragmented (para 1).

134. Voting at the Close of Poll (Twenty-Third Report) (HL Paper 245) None.

135. Referendum on Scottish Independence (Twenty-Third Report) (HL Paper 263) None.

136. Judicial Appointments (Twenty-Fourth Report) (HL Paper 272) None.

\section{2012-2013}

137. Sessional Report (First Report) (HL Paper 16)

None.

138. Crime and Courts Bill (Second Report) (HL Paper 17)

The use of Henry VIII powers should only be contemplated where a full and clear explanation and justification is provided (para 6).

The use of Henry VIII powers should only be permitted if specific purposes are provided for in the Bill, and, if there are adequate procedural safeguards (para 6).

Primary legislation is the appropriate vehicle for constitutionally sensitive subject matter (para 7).

The politicisation of the judicial appointments process should be avoided (para 16).

139. Justice and Security Bill (Third Report) (HL Paper 18)

Legislation should only depart from the principles of open justice and natural justice when it can be demonstrated on the basis of clear evidence that it is necessary (para 10).

The executive should not be allowed to have the dual role in civil proceedings of being a party to the litigation and at the same time being the sole "gatekeeper", controlling access to the possibility that the litigation be conducted in a certain manner(para 18). 
Interference with the courts' ability to decide on the appropriate balance between the competing public interests of national security and the proper administration of justice should be avoided (para 22).

Laws should not grant powers to the Secretary of State that unduly risk the fair administration of justice (para 28).

Case management issues should be decided by the courts and not by Government ministers (para 31).

Henry VIII powers that relate to a constitutionally sensitive subject-matter should use a super-affirmative parliamentary procedure (para 32).

Legislation that departs from principles of open justice and natural justice should be subject to post-legislative scrutiny (para 35).

140. Justice and Security Bill [HL]: Norwich Pharmacal jurisdiction (Fourth Report) (HL Paper 31)

None.

141. Electoral Registration and Administration Bill (Fifth Report) (HL Paper 51) Bills that contain constitutional reform should be preceded by a white paper, public consultation and pre-legislative scrutiny (para 4).

Legislative powers that permit the Secretary of State to affect a constitutionally important right should be subject to effective parliamentary scrutiny (para 13).

142. The Agreement on a referendum on independence for Scotland (Sixth Report) (HL Paper 62)

None.

143. The accountability of civil servants (Seventh Report) (HL Paper 61) None.

144. Police (Complaints and Conduct) Bill (Eighth Report) (HL Paper 80)

When introducing a Bill that is to be fast-tracked, the responsible minister should explain fully why the fast-tracking is necessary, the explanatory notes should address the template of questions set out in the Constitution Committee's report on fast-track legislation (para 4). ${ }^{140}$

Fast-track legislation should not be used to address legal issues that have been known about for a long time (para 7).

Fast-track legislation should be made available to Parliament's legislative scrutiny committees at the earliest possible opportunity, even while the legislation remains in draft form (para 8). 
145. Defamation Bill (Ninth Report) (HL Paper 86)

A Bill which contains provisions of constitutional significance should be preceded by draft legislation, which was subject to public consultation and to pre-legislative scrutiny by a joint committee (para 6).

Rules that are central to a bill of constitutional significance should be to the greatest extent possible on the face of the bill, so allowing full legislative amendment and debate (para 15).

146. Growth and Infrastructure Bill (Tenth Report) (HL Paper 104) Ministerial assurances as to the purpose of order-making powers are not a substitute for legal safeguards on the face of a Bill (para 10).

The policy aims of a Ministerial power should be included in the Bill itself (para 10).

147. The Succession to the Crown Bill (Eleventh Report) (HL Paper 106) When introducing a Bill that is to be fast-tracked, the responsible minister should explain fully why the fast-tracking is necessary, the explanatory notes should address the template of questions set out in the Constitution Committee's report on fast-track legislation (para 13). ${ }^{141}$

The fast-tracking of normal parliamentary procedure should only occur when strictly necessary (para 16).

Bills containing constitutionally significant matters should not be subject to a fasttracked parliamentary procedure (para 20).

148. Jobseekers (Back to Work Schemes) Bill (Twelfth Report) (HL Paper 155) When introducing a Bill that is to be fast-tracked, the responsible minister should explain fully why the fast-tracking is necessary, the explanatory notes should address the template of questions set out in the Constitution Committee's report on fast-track legislation (para 5).

Fast-track legislation should not be used to retrospectively overturn a court judgment in order to deprive an individual of a right (para 10).

Fast-track legislation should not be used to retrospectively overturn a court judgment where there is no compelling operational requirement to amend the law retrospectively (para 10).

Individuals should not be punished or penalised for contravening what was at the time a valid legal requirement (para 13). 
149. The pre-emption of Parliament (Thirteenth Report) (HL Paper 165) None. 


\section{The Constitution Unit}

The project was funded by The Constitution Society.

Department of Political Science

University College London

29-30 Tavistock Square

London WC1H 9QU

phone: 02076794977 fax: 02076794978

email: constitution@ucl.ac.uk

www.ucl.ac.uk/constitution-unit

The Constitution Unit at UCL is the UK's foremost independent research body on constitutional change. It is part of the UCL School of Public Policy.

Robert Hazell founded the Constitution Unit in 1995 to do detailed research and planning on constitutional reform in the UK. The Unit has done work on every aspect of the UK's constitutional reform programme: devolution in Scotland, Wales, Northern Ireland and the English regions, reform of the House of Lords, electoral reform, parliamentary reform, the new Supreme Court, the conduct of referendums, freedom of information, the Human Rights Act. The Unit is the only body in the UK to cover the whole of the constitutional reform agenda.

The Unit conducts academic research on current or future policy issues, often in collaboration with other universities and partners from overseas. We organise regular programmes of seminars and conferences. We do consultancy work for government and other public bodies. We act as special advisers to government departments and parliamentary committees. We work closely with government, parliament and the judiciary. All our work has a sharply practical focus, is concise and clearly written, timely and relevant to policy makers and practitioners.

The Unit has always been multi disciplinary, with academic researchers drawn mainly from politics and law. We also have people with public service backgrounds, and welcome secondments from the public service. We maintain a forward-looking research programme which covers all aspects of the constitution.

The Unit publishes a newsletter, The Monitor, three times a year and many of our publications are available to download from our website. For regular updates, please join our mailing list by completing the online form. 